\title{
Carrot Yield, Quality, and Storability in Relation to Preplant and Residual Nitrogen on Mineral and Organic Soils
}

\author{
Sean M. Westerveld ${ }^{1}$, Mary Ruth McDonald ${ }^{2}$, and \\ Alan W. McKeown ${ }^{2}$
}

AdDitional INDEX wORDs. stand establishment, fresh-market, processing, Daucus carota, nutrient management

Summary. The Nutrient Management Act (NMA) established in the province of Ontario in 2002 has prompted a re-evaluation of nitrogen $(\mathrm{N})$ management practices. However, $\mathbf{N}$ management research in Ontario is currently outdated. The experiment in this 3-year study was designed to establish the yield response of carrot (Daucus carota) to $\mathrm{N}$ fertilization on mineral and organic soils and identify the relative yield effects of preplant and residual soil N. In 2002, N was applied at $0 \%, 50 \%, 100 \%, 150 \%$, and $200 \%$ of recommended $\mathrm{N}$ application rates in Ontario as ammonium nitrate (organic soil: $60 \mathrm{~kg} \cdot \mathrm{ha}^{-1}$ preplant; mineral soil: $110 \mathrm{~kg} \cdot \mathrm{ha}^{-1}$ split $66 \%$ preplant $/ 33 \%$ sidedress). Experimental units were split in half in 2003 and 2004, and $\mathrm{N}$ was applied to one half in 2003 and both halves in 2004 to identify the effects of residual $\mathbf{N}$ from the previous season on yield. Crop stand, yield, and quality were assessed at harvest, and storability was assessed by placing carrots into cold storage for 6 months. Nitrogen application rate had no effect on the yield, quality, or storability of carrots grown on organic soil. On mineral soil there were no effects of applied $\mathrm{N}$ in the first year of the 3-year study. In the second and third year on mineral soil, yield increased in response to increasing $\mathrm{N}$, up to $200 \%$ and $91 \%$ of the recommended application rate, respectively, based on the regression equations. Yield declined above $91 \%$ of the recommended application rate in the third year due to a decrease in stand at higher $\mathrm{N}$ application rates. There were no effects of $\mathrm{N}$ on carrot quality or storability on mineral soil. On mineral soil, residual $\mathrm{N}$ from the 2002 season had more effect on yield at harvest in 2003 than $\mathrm{N}$ applied in 2003. This major effect of residual soil $\mathbf{N}$ on yield provides an explanation for the lack of yield response to preplant $\mathbf{N}$ application in previous studies conducted in temperate regions. These results indicate that there is no single $\mathrm{N}$ recommendation that is appropriate for all years on mineral soil. Assessing the availability of $\mathrm{N}$ from the soil at different depths at seeding is recommended to determine the need for $\mathrm{N}$ application.

$\mathrm{T}$ The recent impetus towards matching $\mathrm{N}$ fertilization with crop $\mathrm{N}$ removal mandated under nutrient management legislation, such as the Nutrient Management Act in Ontario [Ontario Ministry of Agriculture, Food and Rural Affairs (OMAFRA), 2005], could lead to

\footnotetext{
${ }^{1,2}$ Department of Plant Agriculture, University of Guelph, Guelph, Ont., NIG 2W1 Canada.

This paper is a portion of a $\mathrm{PhD}$ thesis submitted by S.M. Westerveld. We thank Kevin Vander Kooi, Marilyn Hovius, and the staff of the Muck Crops Research Station for their assistance. We also thank Cezarina Kora and Kevin Sanderson for reviewing this manuscript. Funding for this work was provided by the Agricultural Adaptation Council through the support of the Ontario Fruit and Vegetable Grower's Association, the Natural Sciences and Engineering Research Council of Canada, and the Ontario Ministry of Agriculture, Food and Rural Affairs/University of Guelph Plant Program.

${ }^{1}$ Postdoctoral Fellow.

${ }^{2}$ Associate Professor.
}

yield reductions for vegetables if relevant research on $\mathrm{N}$ fertilization is not conducted. Research on N nutrition of vegetable crops in Ontario has been minimal over the past few decades. Carrots appear to require little applied $\mathrm{N}$ in temperate regions to achieve optimal yield (Burdine and Hall, 1976; Couper, 2001; Evers, 1988; Gutezeit, 1999; Hamilton and Bernier, 1975; Rühlmann and Geyer, 1993; Sander- son and Ivany, 1997; Venter, 1979; Warncke, 1996; Westerveld, 2002; Wiebe, 1987). There are also minimal effects of $\mathrm{N}$ application rate on quality (Burdine and Hall, 1976; Westerveld, 2002), or long-term storability (Nilsson, 1979; Westerveld, 2002) of carrots. However, no studies have examined the effect of $\mathrm{N}$ on storability under $\mathrm{N}$-deficient conditions.

It is unclear why carrot yields exhibit minimal response to $\mathrm{N}$ application rate in temperate regions. However, mineralization of organic matter could supply the N requirements of the carrot crop (Gutezeit, 1999). In addition, carrots have a deep and extensive root system (Thorup-Kristensen and van den Boogaard, 1999; Westerveld, 2005; White and Strandberg, 1978), and may be accessing residual N applied the previous season that has leached into lower levels of the soil profile.

In contrast, in tropical or subtropical regions such as India, Indonesia, Japan, Texas, and Florida, carrot yields are increased by the application of up to $80,150,210,112$, and $280 \mathrm{~kg} \cdot \mathrm{ha}^{-1}$, respectively (Arora and Mathur, 1972; Burdine and Hall, 1976; Hipp, 1978; Hochmuth et al., 1999; Kumazawa, 2002). This yield response could be attributed to higher rainfall and increased leaching of $\mathrm{N}$ during the winter growing season in these regions (Hochmuth et al., 1999). It is also likely that mining of the soil by successive crops and the highly weathered tropical soils results in minimal residual $\mathrm{N}$ in these experiments.

While many studies have examined the effects of $\mathrm{N}$ on carrot yield and quality, few studies have examined the reasons for the lack of yield response, or the consequences of persistent lack of $\mathrm{N}$ in the long term. Furthermore, the effects of soil residual $\mathrm{N}$ on yield have not been examined, and an examination of these effects could be useful in identifying the situations in which a yield response to $\mathrm{N}$ can be anticipated. The establishment of a carrot yield re-

\begin{tabular}{llll}
\hline $\begin{array}{l}\text { Units } \\
\begin{array}{l}\text { To convert U.S. to SI, } \\
\text { multiply by }\end{array}\end{array}$ & U.S. unit & SI unit & $\begin{array}{l}\text { To convert SI to U.S., } \\
\text { multiply by }\end{array}$ \\
\hline 0.3048 & $\mathrm{ft}$ & $\mathrm{m}$ & 3.2808 \\
0.0929 & $\mathrm{ft}^{2}$ & $\mathrm{~m}^{2}$ & 10.7639 \\
2.54 & inch $(\mathrm{es})$ & $\mathrm{cm}$ & 0.3937 \\
25.4 & inch $(\mathrm{es})$ & $\mathrm{mm}$ & 0.0394 \\
1.1209 & lb/acre & $\mathrm{kg} \cdot \mathrm{ha}^{-1}$ & 0.8922 \\
1 & $\mathrm{ppm}$ & $\mathrm{mg} \cdot \mathrm{kg}^{-1}$ & 1 \\
2.2417 & ton/acre & $\mathrm{t} \cdot \mathrm{ha}^{-1}$ & 0.4461 \\
$\left({ }^{\circ} \mathrm{F}-32\right) \div 1.8$ & 'F & ${ }^{\circ} \mathrm{C}$ & $\left(1.8 \times{ }^{\circ} \mathrm{C}\right)+32$
\end{tabular}


sponse to applied $\mathrm{N}$ is essential for the creation of more efficient $\mathrm{N}$ fertilization recommendations. The purpose of this study was to identify $\mathrm{l}$ ) the $\mathrm{N}$ requirements of the crop for optimum yield, quality, stand, and storability; 2 ) the differences in the $\mathrm{N}$ requirements of the crop between mineral and organic soil and between fresh-market and processing cultivars; and 3 ) the relative importance of preplant and soil residual $\mathrm{N}$ to carrot yield.

\section{Materials and methods}

Field experiments were conducted on mineral and organic soils on the Holland/Bradford Marsh, Ont., Canada (lat. $44^{\circ} 5^{\prime} \mathrm{N}$, long. $79^{\circ} 35^{\prime} \mathrm{W}$ ) at or near the University of Guelph, Muck Crop Research Station, from 2002 to 2004. The organic soil, a Hemic Histosol, contained $60 \%$ to $80 \%$ organic matter and had a $\mathrm{pH}$ of 6.1-6.8. The mineral soil, a Typic Haplaquoll, contained $1.0 \%$ to $3.5 \%$ organic matter, $90 \%$ sand, and had a $\mathrm{pH}$ of 7.9-8.4. Cultivars Idaho and Fontana were used because they represent a fresh-market and a processing cultivar, respectively. Carrots were seeded using a Stan Hay precision seeder (Stan Hay Inc., Ashford, U.K.) into organic soil on 24 May 2002, 2 June 2003, and 21 May 2004 and into mineral soil on 3 June 2002, 2 June 2003, and 20 May 2004. Each experimental unit in the organic soil site in 2002 consisted of eight hills (four hills/cultivar), $5 \mathrm{~m}$ long, $20 \mathrm{~cm}$ high, spaced $86 \mathrm{~cm}$ apart, and seeded at a rate of 80 seeds $/ \mathrm{m}$. Each experimental unit in the mineral soil plot in 2002 consisted of 16 hills (eight hills/cultivar), $10 \mathrm{~m}$ long, $20 \mathrm{~cm}$ high, spaced $86 \mathrm{~cm}$ apart, and seeded at a rate of 80 seeds $/ \mathrm{m}$. The seeds for both soil types were seeded into three lines, $5 \mathrm{~cm}$ apart, on the top of each hill. Mineral soil plots were re-hilled twice during the season in all 3 years, approximately 1 and 2 months after seeding. Nitrogen was applied by hand at $0 \%$ (no applied N), 50\%, $100 \%$ (recommended $\mathrm{N}$ rate), $150 \%$, and $200 \%$ of the Ontario-recommended N rates (OMAFRA, 2004) to the entire experimental unit area in 2002 using ammonium nitrate. The recommendations were $60 \mathrm{~kg} \cdot \mathrm{ha}^{-1} \mathrm{~N}$ applied preplant on organic soil, and $110 \mathrm{~kg} \cdot \mathrm{ha}^{-1}$ $\mathrm{N}$ split 66\% preplant and 33\% sidedress on mineral soil. For 2003 and 2004, each experimental unit was split in half. In 2003 in one half, the same $\mathrm{N}$ rates were applied as in 2002 (annual fertilizer section). In the other half, no $\mathrm{N}$ was applied to identify any effects of residual $\mathrm{N}$ from the 2002 season (alternating fertilizer section). In 2004 , both halves received the same $\mathrm{N}$ rate as was applied in 2002. This allowed for a comparison between carrots given the same $\mathrm{N}$ rate for 3 years consecutively (annual fertilizer) to those given $\mathrm{N}$ for 1 year following no $\mathrm{N}$ application (alternating fertilizer). Carrots were grown on the same site for 3 years in an attempt to reduce residual $\mathrm{N}$ levels and increase the $\mathrm{N}$ response of carrots over time. Even though monoculture is not recommended for carrot production in Ontario, it was necessary for the comparison of the effects of preplant and residual $\mathrm{N}$ for this experiment. For the no N treatment, both halves received no $\mathrm{N}$ fertilizer in all 3 years. Consequently, only one sample was collected for all assessments of this treatment and assumed to represent both sections.

In 2004, assessments were made to document observed seedling death. The number of seedlings per meter was assessed on 11 and 22 June on mineral soil and 11 June on organic soil by counting a random $2.3-\mathrm{m}$ section in the middle rows $\left(2 \mathrm{~m}^{2}\right)$ of both cultivars. These assessments were conducted in the annual fertilizer sections of the plots.

Carrots from the annual fertilizer section of the experiment were handharvested from one (organic 2003 and 2004) and two (organic 2002, and mineral all 3 years) $2.3-\mathrm{m}$ sections of the middle rows of each cultivar and treatment on 18 Oct. 2002, 27 and 28 Oct. 2003 , and 21 Oct. 2004 on organic soil, and 24 Oct. 2002, 23 and 24 Oct. 2003, and 26 Oct. 2004 on mineral soil. Carrots from alternating fertilizer sections were harvested from one $2.3-\mathrm{m}$ section of row for all years and both soil types. For all treatments and experiments, carrots were assessed for total yield, marketable yield, weight per root, stand per meter, and were separated by hand using sizing plates into three grades [diameter $>4.4 \mathrm{~cm}$, $2.0-4.4 \mathrm{~cm}$, and culls (including carrots $<2.0 \mathrm{~cm}$ )]. Since the annual and alternating fertilizer sections represent carrots grown with or without preplant applied N in 2003 and with or without residual $\mathrm{N}$ from $\mathrm{N}$ applied in the previous season in 2004, the relative contribution of preplant and residual
$\mathrm{N}$ (including mineralized $\mathrm{N}$ ) to yield could be determined. The relative contribution of preplant $\mathrm{N}$ was determined by subtracting the yield of the alternating fertilizer section from that of the corresponding annual fertilizer section in 2003 , and by subtracting the yield of the no $\mathrm{N}$ treatment from that of each of the alternating fertilizer sections in 2004. The relative contribution of residual $\mathrm{N}$ was determined by subtracting the yield of the no $\mathrm{N}$ treatment from the yields of each of the alternating fertilizer sections in 2003 , and by subtracting the yield of the annual fertilizer section from that of the corresponding alternating fertilizer section in 2004. The effects of preplant and residual $\mathrm{N}$ on stand were assessed in a similar manner. For the purpose of this paper, residual $\mathrm{N}$ refers to $\mathrm{N}$ in organic or inorganic form that is available to the crop in the current year but applied in or remaining from previous years. When isolating the effects of preplant $\mathrm{N}$ from residual $\mathrm{N}$, the effects of residual $\mathrm{N}$ on yield are solely based on the $\mathrm{N}$ applied in the previous year, since the remainder of the $\mathrm{N}$ would be relatively constant among the treatments. Therefore, when referring to residual $\mathrm{N}, \mathrm{N}$ application rate refers to the $\mathrm{N}$ that was preplant-applied in the previous year.

Marketable carrots from the annual fertilizer section were placed into cold storage $\left(1^{\circ} \mathrm{C}, 95 \%\right.$ relative humidity) for 6 months. After storage, carrots were assessed for percent weight loss, culls, and total loss by weight. Weather data from the University of Guelph, Muck Crops Research Station, are summarized in Table 1 . The experiments were rain-fed only, because no irrigation was available on the sites.

Soil N monitoring, which is the focus of another study, showed that mean initial $\mathrm{N}$ concentrations in the top $30 \mathrm{~cm}$ in Spring 2002 were 24.4 $\mathrm{mg} \cdot \mathrm{kg}^{-1}$ ammonium $\left(\mathrm{NH}_{4}^{+}\right), 89.1$ $\mathrm{mg} \cdot \mathrm{kg}^{-1}$ nitrate $\left(\mathrm{NO}_{3}^{-}\right)$, and $2.4 \%$ total $\mathrm{N}$ for the organic soil plot, and 2.4 $\mathrm{mg} \cdot \mathrm{kg}^{-1} \mathrm{NH}_{4}^{+}, 2.3 \mathrm{mg} \cdot \mathrm{kg}^{-1} \mathrm{NO}_{3}^{-}$, and $0.09 \%$ total $\mathrm{N}$ for the mineral soil plot (Westerveld, 2005). Soil samples were also collected from the recommended rate treatment at harvest in 2002, and from each of the annual fertilizer sections in Spring 2003 and 2004 and Fall 2003 and 2004 (Westerveld, 2005). Soil samples were also collected from the 30-60 $\mathrm{cm}$ and $60-90 \mathrm{~cm}$ depths in Spring and Fall 2004 from three 
replicates of the no $\mathrm{N}$, recommended $\mathrm{N}$ rate, and $200 \%$ of the recommended $\mathrm{N}$ rate treatments (Westerveld, 2005).

The experiments were arranged in a split-block design with cultivar as the main plot and N rate as the sub-plot and four replications. An analysis of variance was performed on each data set to partition the variance into treatment, block, cultivar, soil type, and year effects, and to identify interactions among these effects. Data were analyzed by linear and quadratic regression analysis. The entire data set for each assessment was assessed for normality using the Shapiro-Wilk test of residuals. Outliers were identified using Lund's test of standardized residuals (Lund, 1975). Peak values using quadratic regression equations were determined by setting the slope to zero and solving the first derivative of the regression equation. Data were analyzed using the PROC GLM, PROC CORR, PROC PLOT, and PROC Univariate procedures of SAS (version 8.0; SAS Institute, Cary N.C.). A type I error rate of 0.05 was set for all statistical tests.

\section{Results}

Since there were no significant cultivar $\times$ treatment interactions and both cultivars responded to $\mathrm{N}$ application rate in a similar manner, combined data were reported for all yield and quality parameters. Over the 3-year period in the annual fertilizer section, 3 -year mean yields were $46.6 \mathrm{t} \cdot \mathrm{ha}^{-1}$ ( $\mathrm{SE}$ $=1.12$ ) for 'Idaho' and $43.6 \mathrm{t} \cdot \mathrm{ha}^{-1}$ ( $\mathrm{sE}$ $=1.50$ ) for 'Fontana' on mineral soil, and $81.4 \mathrm{t} \cdot \mathrm{ha}^{-1}(\mathrm{SE}=1.31)$ for 'Idaho' and $81.0 \mathrm{t}^{\circ} \mathrm{ha}^{-1}(\mathrm{SE}=1.89)$ for 'Fontana' on organic soil.

Total yield of carrots grown on organic soil was not affected by $\mathrm{N}$ application rate over the 3 years of the trial in either section of the plots (Table 2 ). Applied $\mathrm{N}$ did not affect the yield of carrots grown on mineral soil in the annual fertilizer section in the first year of production, but it did increase yields in the second and third years (2003 and 2004) of the trial. Yield increased up to $200 \%$ of the recommended rate of $\mathrm{N}$ in 2003 and up to $91 \%$ of the recommended rate in 2004 in the annual fertilizer section, when calculated from the regression equations. In the alternating fertilizer section of the plots in 2003 , which received no $\mathrm{N}$ in 2003 , yield increased with increasing $\mathrm{N}$ rate applied in 2002.

In the alternating fertilizer sec-

Table 1. Monthly mean temperature and rainfall at the University of Guelph, Muck Crops Research Station, Holland/Bradford Marsh, Ont., Canada, from 2002 to 2004 as compared to 10-year means.

\begin{tabular}{|c|c|c|c|c|c|c|c|c|}
\hline \multirow[b]{2}{*}{ Month } & \multicolumn{2}{|c|}{2002} & \multicolumn{2}{|c|}{2003} & \multicolumn{2}{|c|}{2004} & \multicolumn{2}{|c|}{ 10-year } \\
\hline & $\begin{array}{l}\text { Mean } \\
\text { temp } \\
\left({ }^{\circ} \mathrm{C}\right)^{\mathrm{z}}\end{array}$ & $\begin{array}{c}\text { Rainfall } \\
(\mathrm{mm})^{\mathrm{y}}\end{array}$ & $\begin{array}{c}\text { Mean } \\
\text { temp } \\
\left({ }^{\circ} \mathrm{C}\right)\end{array}$ & $\begin{array}{c}\text { Rainfall } \\
(\mathrm{mm})\end{array}$ & $\begin{array}{c}\text { Mean } \\
\text { temp } \\
\left({ }^{\circ} \mathrm{C}\right)\end{array}$ & $\begin{array}{c}\text { Rainfall } \\
(\mathrm{mm})\end{array}$ & $\begin{array}{c}\text { Mean } \\
\text { temp } \\
\left({ }^{\circ} \mathrm{C}\right)\end{array}$ & $\begin{array}{c}\text { Mean } \\
\text { rainfall } \\
(\mathrm{mm})\end{array}$ \\
\hline May & 9.9 & 113 & 12.2 & 105 & 12.4 & 108 & 12.3 & 89 \\
\hline June & 18.2 & 106 & 17.3 & 75 & 16.3 & 50 & 18.0 & 87 \\
\hline July & 21.7 & 76 & 19.9 & 29 & 19.3 & 102 & 19.9 & 73 \\
\hline August & 19.6 & 18 & 20.4 & 81 & 17.8 & 103 & 19.2 & 62 \\
\hline September & 17.5 & 40 & 15.0 & 110 & 16.6 & 25 & 15.4 & 77 \\
\hline October & 7.2 & 49 & 8.0 & 78 & 9.1 & 26 & 8.9 & 65 \\
\hline
\end{tabular}

${ }^{2}\left(1.8 \times{ }^{\circ} \mathrm{C}\right)+32={ }^{\circ} \mathrm{F}$

${ }^{y} 1 \mathrm{~mm}=0.0394$ inch.

Table 2. Effect of annual or alternating nitrogen $(\mathrm{N})$ application rate on total yield of carrots grown in organic or mineral soil for 3 years (average of two cultivars) on the Holland/Bradford Marsh, Ont., Canada.

\begin{tabular}{|c|c|c|c|c|c|c|c|}
\hline \multirow{3}{*}{\multicolumn{2}{|c|}{$\begin{array}{l}\mathrm{N} \text { rate } \\
(\% \text { of } \\
\text { recommended })^{y}\end{array}$}} & \multicolumn{6}{|c|}{ Total yield $\left(\mathrm{t} \cdot \mathrm{ha} \mathrm{a}^{-1}\right)^{\mathrm{z}}$} \\
\hline & & \multirow[b]{2}{*}{2002} & \multicolumn{2}{|r|}{2003} & \multicolumn{2}{|c|}{2004} & \multirow{2}{*}{$\begin{array}{l}\text { 3-year } \\
\text { mean }^{w}\end{array}$} \\
\hline & & & Annual $^{x}$ & Alternating & Annual & Alternating & \\
\hline \multicolumn{8}{|c|}{ Mineral soil } \\
\hline 0 & & $47.7^{\mathrm{v}}$ & $36.1^{v}$ & 36.1 & $38.8^{\mathrm{u}}$ & 38.8 & 40.9 \\
\hline 50 & & 45.5 & 47.6 & 39.4 & 47.1 & 51.7 & 46.7 \\
\hline 100 & & 52.3 & 50.9 & 40.4 & 50.9 & 54.0 & 51.4 \\
\hline 150 & & 40.0 & 54.7 & 47.1 & 47.0 & 48.2 & 47.2 \\
\hline 200 & & 43.4 & 54.6 & 47.1 & 31.6 & 39.9 & 43.2 \\
\hline Mean & & 45.8 & 48.8 & 42.0 & 43.1 & 46.5 & 45.9 \\
\hline \multirow[t]{3}{*}{ Significance } & $\mathrm{L}$ & NS & $* * *$ & * & NS & NS & NS \\
\hline & Q & NS & NS & NS & $* * *$ & $* * *$ & $* * *$ \\
\hline & $\mathrm{R}^{2}$ & --- & 0.60 & 0.30 & 0.58 & 0.65 & 0.49 \\
\hline \multicolumn{8}{|c|}{ Organic soil } \\
\hline 0 & & 95.6 & 78.7 & 78.7 & 71.7 & 71.7 & 82.0 \\
\hline 50 & & 97.0 & 78.8 & 80.1 & 72.7 & 69.5 & 82.8 \\
\hline 100 & & 95.3 & 79.1 & 76.3 & 69.5 & 71.8 & 81.3 \\
\hline 150 & & 94.4 & 74.4 & 77.6 & 72.1 & 72.5 & 80.3 \\
\hline 200 & & 92.1 & 74.7 & 78.5 & 71.7 & 71.9 & 79.5 \\
\hline Mean & & 94.9 & 77.1 & 78.2 & 71.5 & 71.5 & 81.2 \\
\hline \multirow[t]{3}{*}{ Significance } & $\mathrm{L}$ & NS & NS & NS & NS & NS & NS \\
\hline & Q & NS & NS & NS & NS & NS & NS \\
\hline & $\mathrm{R}^{2}$ & --- & --- & --- & --- & --- & --- \\
\hline
\end{tabular}

${ }^{2}$ l tha ${ }^{-1}=0.4461$ ton/acre.

' Recommended rates: organic soil $=60 \mathrm{kgha}^{-1}$ preplant, mineral soil $=110 \mathrm{~kg} \cdot \mathrm{ha}^{-1}$ split $66 \%$ preplant $/ 33 \%$ sidedress $\left(\mathrm{l} \mathrm{kg} \cdot \mathrm{ha}^{-1}=0.8922 \mathrm{lb} /\right.$ acre $)$.

${ }^{\mathrm{x}}$ Annual $=$ fertilized for all 3 years; Alternating $=$ fertilized in 2002 and 2004 only, and 2003 results are based on $2002 \mathrm{~N}$ application.

wAverage of annual fertilizer sections only.

vone outlier removed for reported means and statistical analysis.

"One experimental unit removed due to localized flooding on mineral soil.

Ns, ${ }^{* * *},{ }^{* * *}$ Nonsignificant or significant at $\mathrm{P}=0.05,0.01$, and 0.001 , respectively. $\mathrm{L}=$ linear; $\mathrm{Q}=\mathrm{quadratic} ; \mathrm{R}^{2}=$ coefficient of determination.

tion in 2004 on mineral soil, total yield increased with increasing $\mathrm{N}$ rate up to $99 \%$ of the recommended rate of $\mathrm{N}$ and then decreased at higher $\mathrm{N}$ rates (Table 2), when calculated from the regression equation. In the annual fertilizer section, the mean total yield over the 3 years increased with increasing $\mathrm{N}$ rate up to $102 \%$ of the recommended rate and then decreased at higher $\mathrm{N}$ rates, when calculated from the regression equation. Mean yields in the annual mineral soil plots were significantly higher in 2003 than in 2004. There was a significant decrease in total yield from year to year in the annual fertilizer section on organic soil. Total yields were below provincial average yields [78-90 th.ha ${ }^{-1}$ (OMAFRA, 2004)] for all 3 years on mineral soil. 
However, reported provincial average yields are partly from organic soil, and mineral soil yields are typically lower. On organic soil, mean total yields were above provincial averages in 2002 and declined to slightly below average in 2004 (Table 2).

Nitrogen application rate had an effect on early season survival of carrots. The number of live seedlings per meter in early June 2004 in the annual fertilizer section decreased with increasing $\mathrm{N}$ rate on mineral soil (Table 3 ). The stand $11 \mathrm{~d}$ later was thinner, especially in the high $\mathrm{N}$ treatments. The number of visible dead seedlings at the early assessment date increased with increasing $\mathrm{N}$ rate, but could not account for the majority of the missing plants in the high $\mathrm{N}$ treatments. There was no effect of $\mathrm{N}$ rate on stand or the number of visible dead seedlings per meter early in the season on organic soil. Although both cultivars exhibited similar effects of $\mathrm{N}$ on stand early in the season, 'Idaho' had better seedling emergence than 'Fontana' on both assessment dates (data not shown).

Carrot stand at harvest increased slightly with increasing $\mathrm{N}$ rate in 2002 on both soil types up to a maximum at $73.8 \%$ of the recommended rate on mineral soil and $58.0 \%$ of the recommended rate on organic soil, and then decreased slightly at $\mathrm{N}$ rates above the optimum (Table 4). In 2003 on mineral soil in the annual fertilizer section, and in 2004 in both sections, stand at harvest decreased with increasing $\mathrm{N}$ rate. Carrot stand at harvest was much higher in 2003 than in the other 2 years on mineral soil. On organic soil in 2003 and 2004 there was no effect of $\mathrm{N}$ rate on stand at harvest. In most cases 'Idaho' had a denser stand at harvest than 'Fontana' on both soil types (data not shown).

After isolating the effects of preplant $\mathrm{N}$ from the effects of residual $\mathrm{N}$ from the previous season, there was no effect of preplant or residual $\mathrm{N}$ on total yield or stand on organic soil in 2003 or 2004 (data not shown). On mineral soil in 2003, yield increased with increasing residual $\mathrm{N}$, but there was no significant effect of preplant $\mathrm{N}$ alone on yield (Fig. 1). However, it appears that the maximum effect of preplant $\mathrm{N}$ occurred at the recommended $\mathrm{N}$ rate and the response to preplant $\mathrm{N}$ declined above that rate. In 2004 on mineral soil, yield increased with increasing
Table 3. Effect of annual nitrogen $(\mathrm{N})$ application rate on carrot stand in the seedling stage in mineral and organic soil in 2004 on the Holland/ Bradford Marsh, Ont., Canada [average of two cultivars; seeding rate 80 seeds /m (24.4 seeds/ft)].

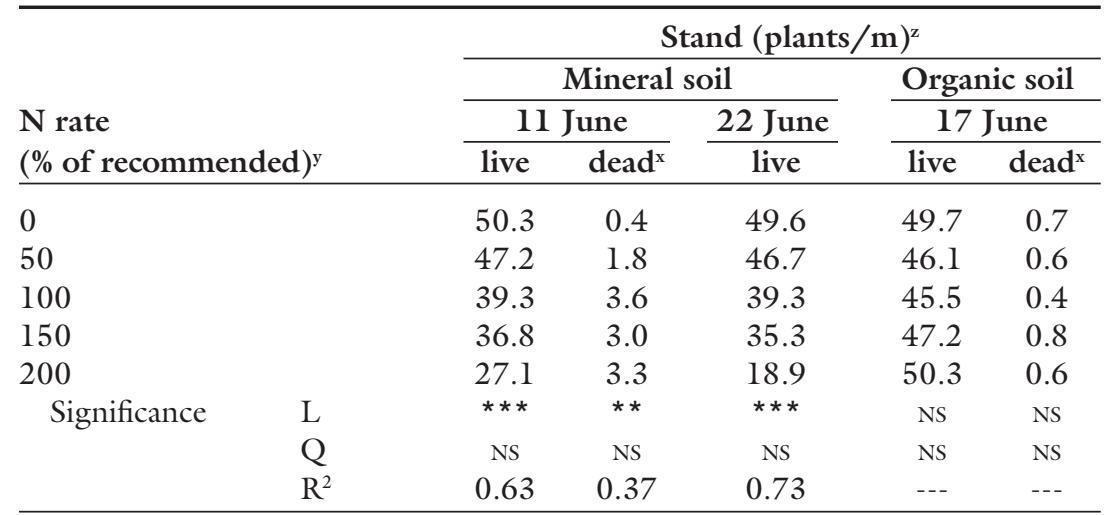

${ }^{\mathrm{z}} \mathrm{l}$ plant $/ \mathrm{m}=0.3048$ plant $/ \mathrm{ft}$.

'Recommended rates: organic soil $=60 \mathrm{~kg} \cdot \mathrm{ha}^{-1} \mathrm{~N}$ preplant, mineral soil $=110 \mathrm{~kg} \cdot \mathrm{ha}^{-1}$ split $66 \%$ preplant $/ 33 \%$ sidedress $\left(1 \mathrm{~kg} \cdot \mathrm{ha}^{-1}=0.8922 \mathrm{lb} /\right.$ acre $)$.

xPlants visible but dead at the time of assessment.

Ns, ${ }^{*}{ }^{* *},{ }^{* * *}$ Nonsignificant or significant at $P=0.05,0.01$, and 0.001 , respectively. $\mathrm{L}=$ linear; $\mathrm{Q}=$ quadratic; $\mathrm{R}^{2}=$ coefficient of determination.

Table 4. Effect of annual and alternating nitrogen $(\mathrm{N})$ application rate on stand at harvest of carrots grown in mineral and organic soil on the Holland/Bradford Marsh, Ont., Canada, for 3 years and seeded at a rate of 80 seeds $/ \mathrm{m}(24.4$ seeds/ft)(average of two cultivars).

\begin{tabular}{|c|c|c|c|c|c|c|c|}
\hline \multirow{3}{*}{\multicolumn{2}{|c|}{$\begin{array}{l}\mathrm{N} \text { rate } \\
(\% \text { of } \\
\text { recommended })^{\mathrm{y}}\end{array}$}} & \multirow[b]{3}{*}{2002} & \multicolumn{4}{|c|}{ Stand at harvest (roots $/ \mathrm{m}$ of row) $\mathrm{z}$} & \multirow{3}{*}{$\begin{array}{l}\text { 3-year } \\
\text { mean }^{\mathrm{w}}\end{array}$} \\
\hline & & & \multicolumn{2}{|c|}{2003} & \multicolumn{2}{|c|}{2004} & \\
\hline & & & Annual $^{\mathrm{x}}$ & Alternating & Annual & Alternating & \\
\hline \multicolumn{8}{|c|}{ Mineral soil } \\
\hline 0 & & $35.1^{\mathrm{v}}$ & 74.1 & 74.1 & 48.8 & 48.8 & 52.7 \\
\hline 50 & & 41.7 & 71.2 & 66.5 & 46.4 & 41.9 & 53.1 \\
\hline 100 & & 39.9 & 68.3 & 65.8 & 34.7 & 31.4 & 47.6 \\
\hline 150 & & 32.5 & 58.6 & 65.0 & 28.9 & 29.4 & 40.0 \\
\hline 200 & & 30.2 & 45.1 & 57.0 & 17.4 & 20.5 & 30.9 \\
\hline Mean & & 35.9 & 63.5 & 65.7 & 35.2 & 34.4 & 44.9 \\
\hline \multirow[t]{3}{*}{ Significance } & $\mathrm{L}$ & * & $* * *$ & NS & $* * *$ & $* * *$ & $* * *$ \\
\hline & $Q$ & * & NS & NS & NS & NS & * \\
\hline & $\mathrm{R}^{2}$ & 0.39 & 0.57 & --- & 0.80 & 0.62 & 0.75 \\
\hline \multicolumn{8}{|c|}{ Organic soil } \\
\hline 0 & & $52.3^{\mathrm{w}}$ & 59.9 & 59.9 & 46.9 & 46.9 & 53.0 \\
\hline 50 & & 62.7 & 64.7 & 56.2 & 44.8 & 46.1 & 54.6 \\
\hline 100 & & 60.6 & 61.5 & 49.4 & 44.1 & 41.9 & 55.4 \\
\hline 150 & & 59.4 & 56.2 & 52.9 & 43.5 & 49.8 & 53.0 \\
\hline 200 & & 53.8 & 56.9 & 53.2 & 48.3 & 45.1 & 53.0 \\
\hline Mean & & 57.8 & 59.8 & 54.3 & 45.5 & 46.0 & 54.4 \\
\hline \multirow[t]{3}{*}{ Significance } & $\mathrm{L}$ & * & NS & NS & NS & NS & NS \\
\hline & $Q$ & * & NS & NS & NS & NS & NS \\
\hline & $\mathrm{R}^{2}$ & 0.42 & --- & --- & --- & --- & \\
\hline
\end{tabular}

${ }^{2} 1 \mathrm{root} / \mathrm{m}$ of row $=0.3048$ roots $/ \mathrm{ft}$ of row.

${ }^{\mathrm{y}}$ Recommended rates: organic soil $=60 \mathrm{~kg} \cdot \mathrm{ha}^{-1} \mathrm{~N}$ preplant, mineral soil $=110 \mathrm{~kg} \cdot \mathrm{ha}^{-1}$ split $66 \%$ preplant $/ 33 \%$ sidedress $\left(1 \mathrm{~kg} \cdot \mathrm{ha}^{-1}=0.8922 \mathrm{lb} /\right.$ acre $)$.

${ }^{x}$ Annual $=$ fertilized for all 3 years; Alternating = fertilized in 2002 and 2004 only, and 2003 results are based on $2002 \mathrm{~N}$ application.

"Average of annual fertilizer sections only.

'One outlier removed for the reported means and statistical analysis.

Ns, ${ }^{*},{ }^{* *},{ }^{* *}$ Nonsignificant or significant at $P=0.05,0.01$, and 0.001 , respectively. $\mathrm{L}=$ linear; $\mathrm{Q}=$ quadratic; $\mathrm{R}^{2}=$ coefficient of determination. 

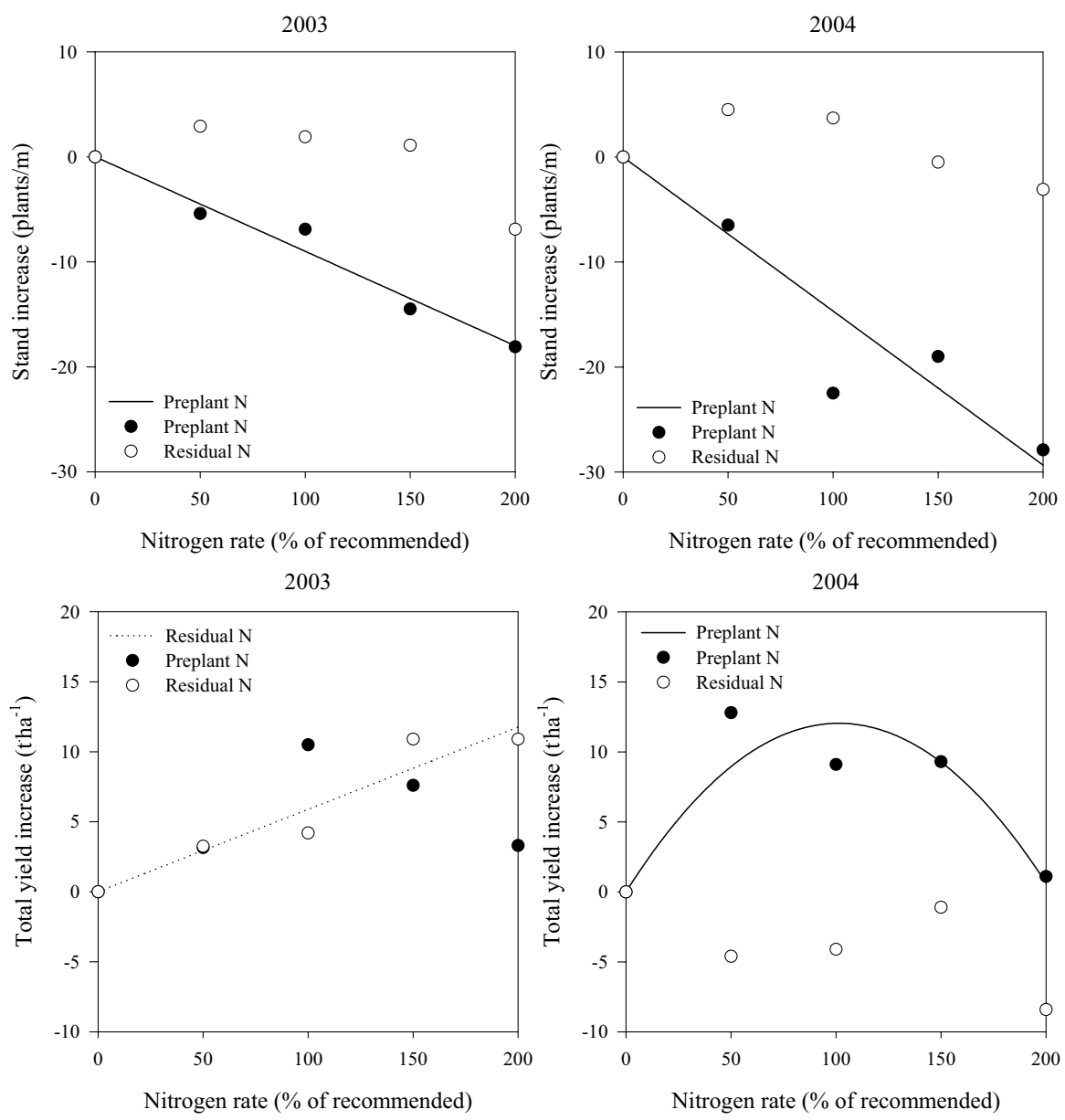

Fig. 1. Increase in total yield and stand attributed to preplant-applied nitrogen $(\mathrm{N})$ and residual $\mathrm{N}$ from the previous season at five $\mathrm{N}$ application rates for carrots grown in mineral soil in 2003 and 2004 on the Holland/Bradford Marsh, Ont., Canada $\left(1 \mathrm{~kg} \cdot \mathrm{ha}^{-1}=0.8922 \mathrm{lb} /\right.$ acre, $1 \mathrm{t} \cdot \mathrm{ha}^{-1}=0.4461 \mathrm{ton} / \mathrm{acre}, 1 \mathrm{plant} / \mathrm{m}$ $=0.3048$ plant $/ \mathrm{ft}$ ). Recommended rate is $110 \mathrm{~kg} \cdot \mathrm{ha}^{-1}$ split $66 \%$ preplant $/ 33 \%$ sidedress for mineral soil. The no $\mathrm{N}$ treatment was assumed to have $0 \mathrm{t} \cdot \mathrm{ha}^{-1}$ yield increase or 0 plants $/ \mathrm{m}$ increase for both the preplant and residual $\mathrm{N}$ plots. Regression statistics: Preplant $\mathrm{N}-$ Stand 2003: $\mathrm{P}<0.0001 \mathrm{R}^{2}=0.41 \mathrm{Y}=-0.0900 \mathrm{X}$; Preplant $\mathrm{N}-$ Stand 2004: $\mathrm{P}<0.0001 \mathrm{R}^{2}=0.51 \mathrm{Y}=-0.1467 \mathrm{X}$; Residual $\mathrm{N}-$ Total yield 2003: $\mathrm{P}<0.0001 \mathrm{R}^{2}=0.30 \mathrm{Y}=0.0588 \mathrm{X}$; Preplant $\mathrm{N}-$ Total yield 2004: $\mathrm{P}$ $=0.0004 R^{2}=0.32 \mathrm{Y}=0.2376 \mathrm{X}-0.00117 \mathrm{X}^{2}$.

preplant $\mathrm{N}$ up to the recommended $\mathrm{N}$ rate and then decreased above the recommended rate, but there was no effect of residual $\mathrm{N}$ on yield. In both years on mineral soil, stand decreased with increasing preplant $\mathrm{N}$, but was not affected by residual $\mathrm{N}$ from the previous season.

The effect of $\mathrm{N}$ application rate on marketable yield followed the same pattern as total yield, but declined more over the 3 years compared to total yield (data not shown). Weight per root was only influenced by $\mathrm{N}$ application rate when stand was affected, since there was a strong negative correlation between weight per root and stand at harvest in all years (mineral soil 3-year mean $r=-0.86$; organic soil 3-year mean $\mathrm{r}=-0.82$, data not shown). The distribution of carrots among the three size and quality grades was mainly influenced by weight per root differences. The proportion of carrot roots that were culls increased with increasing $\mathrm{N}$ rate in 2004 on mineral soil as a result of an increase in forking (branching of the fleshy portion of the taproot) and aster yellows (aster yellows phytoplasma). There was also an increase in culls with increasing $\mathrm{N}$ application rate in the alternating section of the plots due to more forking and splitting at the high $\mathrm{N}$ application rates. There were no differences in the pattern of cultivar response to $\mathrm{N}$ application rate, but 'Fontana' generally had higher weight per root than 'Idaho', and 'Idaho' generally had a higher proportion of culls due to small carrots on mineral soil.

With one exception there was no effect of $\mathrm{N}$ rate on losses in storage on both soil types (Table 5). However, there was a decrease in the number of cull roots due to rots and sprouting in storage with increasing $\mathrm{N}$ rate on mineral soil in 2003. 'Idaho' carrots exhibited more weight loss in storage than 'Fontana' carrots in most cases, but 'Fontana' carrots exhibited more losses due to culls in most cases.

'Fontana' carrots were observed to have weaker and smaller canopies over the second half of the growing season than 'Idaho' carrots. Aster yellows was observed to increase each year of the experiment on mineral soil, and became severe in 2004. The largest amount of aster yellows appeared to occur in the areas where seedling damage due to high $\mathrm{N}$ occurred. Wilting symptoms due to low rainfall were visible in both 2002 and 2003 on mineral soil, but only occurred for a 2- to 4-week period in small areas of the plot.

\section{Discussion}

Similar to previous research in temperate regions (Burdine and Hall, 1976; Couper, 2001; Evers, 1988; Gutezeit, 1999; Hamilton and Bernier, 1975; Rühlmann and Geyer, 1993; Sanderson and Ivany, 1997; Venter, 1979; Warncke, 1996; Westerveld, 2002; Wiebe, 1987), carrot yield did not respond to $\mathrm{N}$ application rate or preplant available $\mathrm{N}$ on organic soil in this study. These results suggest that there was sufficient $\mathrm{N}$ released by mineralization of organic matter over the growing season or there was sufficient residual $\mathrm{N}$ to supply the $\mathrm{N}$ requirements of the crop for optimal storage root growth. No negative effects of either high or low $\mathrm{N}$ application rates on the storage root could be identified. The results are in contrast to reports from tropical and subtropical regions, showing a large yield response to applied $\mathrm{N}$ (Arora and Mathur, 1972; Burdine and Hall, 1976; Hipp, 1978; Hochmuth et al., 1999; Kumazawa, 2002). It is likely that the differences between temperate and tropical regions are mainly due to less rainfall, resulting in less leaching in temperate regions during the car- 
Table 5. Effect of annual nitrogen $(\mathrm{N})$ application rate on the decrease in weight and marketable roots after 6 months of cold storage for carrots grown in organic and mineral soil on the Holland/Bradford Marsh, Ont., Canada, for 3 years (average of two cultivars).

\begin{tabular}{|c|c|c|c|c|c|c|c|c|c|c|}
\hline \multirow{2}{*}{\multicolumn{2}{|c|}{$\begin{array}{l}\mathrm{N} \text { rate } \\
(\% \text { of recommended })^{z}\end{array}$}} & \multicolumn{3}{|c|}{ Wt loss (\%) } & \multicolumn{3}{|c|}{ Cull losses (\%) } & \multicolumn{3}{|c|}{ Total loss (\%) } \\
\hline & & 2002 & 2003 & 2004 & 2002 & 2003 & 2004 & 2002 & 2003 & 2004 \\
\hline \multicolumn{11}{|c|}{ Mineral soil } \\
\hline 50 & & 6.4 & 7.8 & 10.5 & 2.0 & 2.6 & 2.1 & 8.4 & 11.4 & 12.6 \\
\hline 100 & & 6.2 & 7.9 & 10.7 & 0.0 & 1.5 & 0.1 & 6.2 & 9.4 & 10.8 \\
\hline \multirow[t]{3}{*}{ Significance } & $\mathrm{L}$ & NS & NS & NS & NS & * & NS & NS & NS & NS \\
\hline & $\mathrm{Q}$ & NS & NS & NS & NS & NS & NS & NS & NS & NS \\
\hline & $\mathrm{R}^{2}$ & --- & --- & --- & --- & 0.28 & --- & --- & --- & --- \\
\hline \multicolumn{11}{|c|}{ Organic soil } \\
\hline 0 & & 4.4 & 7.0 & 5.7 & 1.8 & 7.0 & 1.0 & 6.3 & 13.9 & 6.8 \\
\hline \multirow[t]{3}{*}{ Significance } & $\mathrm{L}$ & NS & NS & NS & NS & NS & NS & NS & NS & NS \\
\hline & Q & NS & NS & NS & NS & NS & NS & NS & NS & NS \\
\hline & $\mathrm{R}^{2}$ & --- & --- & --- & --- & --- & --- & --- & --- & --- \\
\hline
\end{tabular}

${ }^{2}$ Recommended rates: organic soil $=60 \mathrm{~kg} \cdot \mathrm{ha}^{-1} \mathrm{~N}$ preplant, mineral soil $=110 \mathrm{~kg} \cdot \mathrm{ha}^{-1}$ split $66 \%$ preplant $/ 33 \%$ sidedress $\left(1 \mathrm{~kg} \cdot \mathrm{ha}{ }^{-1}=0.8922 \mathrm{lb} / \mathrm{acre}\right)$

"Two outliers removed.

Ns, ${ }^{\star},{ }^{* \star},{ }^{* \star \star}$ Nonsignificant or significant at $P=0.05,0.01$, and 0.001 , respectively. $\mathrm{L}=$ linear; $\mathrm{Q}=$ quadratic; $\mathrm{R}^{2}=$ coefficient of determination.

rot growing season (Hochmuth et al., 1999). It is also possible that successive crop production over the year results in low residual $\mathrm{N}$ levels in these regions, such as the $60 \mathrm{~kg} \cdot \mathrm{ha}^{-1}$ available in the top $120 \mathrm{~cm}$ of the soil profile prior to seeding in the Texas study (Hipp, 1978). In temperate regions, carrots may have the opportunity to take up $\mathrm{N}$ from deep in the soil profile because the slower leaching rates, due to the soils being frozen for up to 4 months of the year, result in a significant pool of $\mathrm{N}$ remaining from the previous season (Ryan et al., 2000; Sheppard and Bates, 1986). However, growing carrots with minimal applied $\mathrm{N}$, regardless of the amount of residual $\mathrm{N}$, causes an increase in alternaria leaf blight (Alternaria dauci) and cercospora leaf blight (Cercospora carotae), and this effect should be considered in $\mathrm{N}$ fertilization practices (Westerveld, 2005).

On mineral soil, there was also no response to applied $\mathrm{N}$ in the first year of the experiment. The mineral soil site had remained fallow with extensive weed cover for several years prior to the 2002 season, which could have caused an accumulation of organic matter with a low carbon: $\mathrm{N}(\mathrm{C}: \mathrm{N})$ ratio by the 2002 season. This may have resulted in a large release of $\mathrm{N}$ by mineralization, and could explain the lack of $\mathrm{N}$ effect on yield in 2002 . Since no yield response to applied $\mathrm{N}$ occurred in the first year, carrots may not require $\mathrm{N}$ application when grown within a crop rotation, but the response to applied $\mathrm{N}$ would depend on residual $\mathrm{N}$ from the preceding crop. Previous research in Yugoslavia reveals that carrot yield depends on the preceding crop, with onions (Allium cepa), potatoes (Solanum tuberosum), chicory (Cichorium intybus), and peppers (Capsicum annumm) being the most beneficial for high carrot yields (Markovic et al., 2002). The reasons for these effects were not examined, but it is likely that residual nutrition plays a significant role.

Likely due to the low organic matter content of the soil on this site, lower mineralization rates over time, and removal of residual $\mathrm{N}$ from the soil in 2002 , both sections of the experiment in 2003 revealed an increase in yield and weight per root with increasing $\mathrm{N}$ rate up to the maximum rate tested. The yield response to $\mathrm{N}$ rate in the alternating fertilizer section suggests that a significant amount of $\mathrm{N}$ that was unused in 2002 was still available to the crop by 2003. This is supported by the comparison between preplant and residual $\mathrm{N}$ in 2003, which showed that residual $\mathrm{N}$ caused a steady increase in yield, while preplant $\mathrm{N}$ caused no significant trend in yield, mainly due to decreased stand at higher $\mathrm{N}$ application rates. Since the taproot extends below $38.5-\mathrm{cm}$ depth at $24 \mathrm{~d}$ after seeding (White and Strandberg, 1978), carrots may be able to access deep $\mathrm{N}$ early in the season. Given that rainfall was below normal in the first 3 months of the 2003 growing season, it is possible that the $\mathrm{N}$ applied in 2003 remained in the dry top layers of the soil where it would be less accessible to the crop. The induction of deep rooting due to low soil moisture could have caused roots to take up $\mathrm{N}$ in deep layers of the profile. If there was insufficient time for preplant-applied $\mathrm{N}$ to leach into the rooting zone, a higher response to soil residual $\mathrm{N}$ would be expected and this is likely the cause for the results obtained in 2003. The results also suggest that little $\mathrm{N}$ leached out of the rooting zone over Winter 2002-03, even though the soil at this site was more than $90 \%$ sand. Rainfall during late Summer and Fall 2002 was well below the 10-year mean. However, rainfall was above normal in the month prior to seeding in 2003. Under similar conditions, leaching losses of $\mathrm{N}$ over the winter are variable among sites and among years in New Brunswick, 
with $10 \%$ to $87 \%$ losses in sandy soils (Zebarth et al., 2003), and leaching is minimal when soils are frozen in Ontario (Ryan et al., 2000). Assessing the amount of $\mathrm{N}$ available from all layers of the soil profile early in the season could improve $\mathrm{N}$ management of the crop.

A concurrent study on these plots revealed inconsistent soil $\mathrm{N}, \mathrm{NO}_{3}-\mathrm{N}$, and $\mathrm{NH}_{4}-\mathrm{N}$ concentrations in the top $30 \mathrm{~cm}$ among the years, and critical concentrations at seeding could not be established (Westerveld, 2005). This result suggests that $\mathrm{N}$ concentrations in the top $30 \mathrm{~cm}$ of the soil profile do not provide a good indication of the $\mathrm{N}$ available to the crop at seeding. Since carrots exhibit deep rooting and there was an accumulation of $\mathrm{N}$ at seeding between 30 and $90 \mathrm{~cm}$ below the surface when excess $\mathrm{N}$ was applied in the previous year on both mineral and organic soils (Westerveld, 2005), it is likely that residual $\mathrm{N}$ was an important source of $\mathrm{N}$ for the carrot crop in these plots.

In 2004 on mineral soil, yield reached a maximum below the recommended rate and then declined at higher $\mathrm{N}$ rates. This result can be attributed to a major loss of stand in the high $\mathrm{N}$ treatments in both sections of the experiment. Based on the comparison between preplant and residual $\mathrm{N}$, the decrease in stand can be entirely attributed to preplant $\mathrm{N}$. However, since both halves received N, any residual $\mathrm{N}$ could have compounded the effects on stand, and resulted in minimal effects of residual $\mathrm{N}$ on yield. Research reveals a decrease of $9 \%$ to $13 \%$ in carrot stand with increasing $\mathrm{N}$ rate in Oregon, but the reason for the effect was not investigated (Hemphill and Jackson, 1982). It is unclear what caused the seedling death shown in 2003 and in 2004 in this study, but several possibilities exist. Direct toxicity of $\mathrm{N}$ to seedlings is possible, but it would have had to occur under very specific weather and soil conditions because similar $\mathrm{N}$ application rates in other years did not result in the same stand effect (Westerveld, 2002). It is also possible that the high $\mathrm{N}$ treatment promoted the development of seedling diseases, such as damping-off (Pythium spp.). Since the effect on stand increased each year of the experiment, it is possible that inoculum of the causal organisms accumulated over the 3 years, resulting in the major damage in 2004. Visual observation of plants that died later in the season in 2004 showed symptoms of crown rot caused by Rhizoctonia solani and heat canker. However, the heat canker cannot provide an explanation for the effects at the seedling stage since most of the missing seedlings did not emerge from the ground, and it is unlikely that $\mathrm{N}$ rate could affect the susceptibility of seedlings to heat canker. Heat canker damage may have been increased by the thin stands that occurred later in the season in high $\mathrm{N}$ treatments. Nitrate fertilizer increases the growth of $R$. solani in culture, and $\mathrm{NH}_{4}{ }^{+}$fertilizer increases carrot infection by $R$. solani (Ghini et al., 2001). It is not known what the relative proportion of the $\mathrm{NO}_{3}{ }^{-}$and $\mathrm{NH}_{4}{ }^{+}$forms were at the time of seedling emergence in the current experiment. Damping-off of peas (Pisum sativum) and cotton (Gossypium hirsutum) caused by $R$. solani and Pythium ultimum is reduced with addition of composted sewage sludge, a result that is negatively correlated with $\mathrm{N}$ concentration, but many other nutrient and microbial interactions are possible (Lewis et al., 1992). There is no effect of soil $\mathrm{N}$ status on seedling diseases of sorghum (Sorghum bicolor), including Alternaria spp. and Fusarium spp. (McLaren, 2004). In the present experiment, crown rot was not noted in 2003 , when a smaller but still significant effect of $\mathrm{N}$ on stand occurred.

The results on mineral soil in 2003 and 2004 reveal that growing carrots on the same location for consecutive years depletes soil $\mathrm{N}$, resulting in a yield response. However, the same result did not occur on organic soil. It is unknown if further growth of carrots on the same organic soil location for more years would result in a yield effect. Further research is recommended to examine an organic soil carrot/onion rotation for effects of $\mathrm{N}$ on crop yield, since this crop rotation is predominant on the Holland Marsh in Ontario.

Yield generally decreased over time in both plots despite an increase in rainfall in the latter 2 years. On mineral soil, the decrease in stand at high $\mathrm{N}$ rates in 2004 partially explains the reduction in yield. On organic soil, where no effects on stand occurred, there are two possible explanations for the reduction in yield. First, pest pressures, including carrot rust fly (Psila rosae) and aster yellows, increased each year of the study, probably due to the lack of crop rotation. Second, in each year there was a period of below normal rainfall that occurred earlier each year. It is possible that plant development was more affected by dry conditions early in the season, possibly due to a less extensive root system and inability to access deep soil moisture at this time, or by affecting the early development of the storage root. These results highlight the importance of proper crop rotation.

The increase in culls that occurred in some cases at high $\mathrm{N}$ rates in 2004 could be attributed to increased aster yellows and forking of carrot roots on mineral soil, and increased forking and splitting of carrot roots on organic soil. On mineral soil, these effects are probably a direct result of partial damage that occurred in the seedling stage due to the same problem that decreased stand. The increase in aster yellows could be due to preferential feeding by the vector, the aster leafhopper (Macrosteles quadrilineatus). A relationship between $\mathrm{N}$ fertilization and leafhoppers has been noted previously for other leafhopper species and hosts (Bentz and Townsend, 2003; Rossi and Strong, 1991). Splitting is affected by $\mathrm{N}$ application rates in previous studies. High sidedress $\mathrm{N}$ applications in midJuly increases splitting (Bienz, 1965) and above-optimum preplant $\mathrm{N}$ application rates increase carrot cracking at harvest (Hartz et al., 2005).

The only effect of $\mathrm{N}$ application rate on storability occurred in 2003 on mineral soil. This effect is probably due to the small size of some of the roots in the low $\mathrm{N}$ treatments, which lost moisture rapidly and became susceptible to storage diseases, such as bacterial soft rot (Erwinia carotavora ssp. carotavora). It could be concluded from these results that early season $\mathrm{N}$ application had little or no effect on carrot quality or storability other than the effects on root size and stand, confirming previous reports (Burdine and Hall, 1976; Nilsson, 1979; Westerveld, 2002).

The results of the present study indicated that the $\mathrm{N}$ requirements of carrots for optimum storage root yield depended on the climate, soil, and residual soil $\mathrm{N}$ from the previous season. Residual $\mathrm{N}$ had more effect on yield than preplant-applied $\mathrm{N}$ in 2003 on mineral soil, and this provides some explanation for the minimal effects of 
$\mathrm{N}$ on carrot yield in previous experiments. Overapplication of $\mathrm{N}$ caused major losses due to seedling damage on mineral soil in 2003 and 2004 and occurred at $\mathrm{N}$ rates that provided optimal yields in previous years. This is the first study to show a major effect of $\mathrm{N}$ application rate on carrot stand, and this effect was probably increased by growing carrots on the same site for 3 years. Despite the establishment of an $\mathrm{N}$ deficiency on mineral soil in 2003 and 2004, there was no effect of $\mathrm{N}$ application rate on carrot quality or storability. There is no single $\mathrm{N}$ recommendation that is appropriate for all years. Consequently, assessing the $\mathrm{N}$ availability from the soil at both 0-30 cm depth, which is important for determining the risk of stand loss from $\mathrm{N}$ application, and $30-90 \mathrm{~cm}$ depth, which can account for residual $\mathrm{N}$ from previous seasons, may be required to determine if $\mathrm{N}$ application is necessary and to prevent crop losses from excess $\mathrm{N}$ application.

\section{Literature cited}

Arora, P.N. and R.B.L. Mathur. 1972. Note on effect of nitrogen and potash on the yield of carrots. Indian J. Agron. 17:116-117.

Bentz, J.A. and A.M. Townsend. 2003. Nitrogen fertilization and use of containergrown maple selections as hosts by the potato leafhopper. J. Amer. Soc. Hort. Sci. 128:821-826.

Bienz, D.R. 1965. Carrot splitting and second growth in central Washington as influenced by spacing, time of sidedressing and other cultural practices. J. Amer. Soc. Hort. Sci. 86:406-410.

Burdine, H.W. and C.B. Hall. 1976. Carrot responses to fertilizer levels on Everglades organic soils. Proc. Florida State Hort. Soc. $89: 120-125$.

Couper, G. 2001. The biology, epidemiology and control of Sclerotinia sclerotiorum on carrots in north east Scotland. PhD Diss., Univ. of Aberdeen, Aberdeen, Scotland, U.K.

Evers, A. 1988. Effects of different fertilization practices on the growth, yield and dry matter content of carrot. J. Agr. Sci. Finland 60:135-152.

Ghini, R., W. Bettiol, J.F. Dynia, and A.H.N. Maia. 2001. Effect of nitrogen fertilizers on the soil suppressiveness to plant pathogens. Ecossistema 26:147-151.
Gutezeit, B. 1999. Yield and nitrate content of carrots (Daucus carota L.) as affected by nitrogen supply. Acta Hort. 506:87-91.

Hamilton, H.A. and R. Bernier. 1975. N$\mathrm{P}-\mathrm{K}$ fertilizer effects on yield, composition and residues of lettuce, celery, carrot and onion grown on an organic soil in Quebec. Can. J. Plant Sci. 55:453-461.

Hartz, T.K., P.R. Johnstone, and J.J. Nunez. 2005. Production environment and nitrogen fertility affect carrot cracking. HortScience 40:611-615.

Hemphill, D.D. Jr. and T.L. Jackson. 1982. Effect of soil acidity and nitrogen on yield and elemental concentration of bush bean, carrot, and lettuce. J. Amer. Soc. Hort. Sci. 107:740-744.

Hipp, B.W. 1978. Response by carrots to nitrogen and assessment of nitrogen status by plant analysis. HortScience 13:43-44.

Hochmuth, G.J., J.K. Brecht, and M.J. Bassett. 1999. Nitrogen fertilization to maximize carrot yield and quality on a sandy soil. HortScience 34:641-645.

Kumazawa, K. 2002. Nitrogen fertilization and nitrate pollution in groundwater in Japan: Present status and measures for sustainable agriculture. Nutrient Cycling Agroecosystems 63:129-137.

Lewis, J.A., R.D. Lumsden, P.D. Millner, and A.P. Keinath. 1992. Suppression of damping-off of peas and cotton in the field with composted sewage sludge. Crop Protection 11:260-266.

Lund, R.E. 1975. Tables for an approximate test for outliers in linear models. Technometrics 17:473-476.

Markovic, V., Z. Ilin, M. Djurovka, and B. Dazic. 2002. Effect of preceeding crop on growth dynamics, yield and quality of carrot. Acta Hort. 579:363-366.

McLaren, N.W. 2004. Effect of soil nutrient status on severity of seedling diseases and root rot of sorghum (Sorghum bicolor). South African J. Plant Soil 21:263-265.

Nilsson, T. 1979. Yield, storage ability, quality and chemical composition of carrot, cabbage and leek at conventional and organic fertilizing. Acta Hort. 93:209-215.

Ontario Ministry of Agriculture, Food and Rural Affairs. 2004. Vegetable production recommendations. Publ. 363, Queen's Printer for Ontario, Toronto.

Ontario Ministry of Agriculture, Food and Rural Affairs. The Nutrient Management Act. 21 Oct. 2005. <http://www.omafra. gov.on.ca/english/nm/act.html>.
Rossi,A.M. and D.R. Strong. 1991. Effects of host-plant nitrogen on the preference and performance of laboratory populations of Carneocephala floridana (Homoptera: Cicadellidae). Environ. Entomol. 20:1349-1355.

Rühlmann, J. and B. Geyer. 1993. Validation of a simulation model for carbon and nitrogen dynamics in soil in a field trial. Acta Hort. 339:75-84.

Ryan, M.C., R.G. Kachanoski, and R.W. Gillham. 2000. Overwinter soil nitrogen dynamics in seasonally frozen soils. Can. J. Soil Sci. 80:541-550.

Sanderson, K.R. and J.A. Ivany. 1997. Carrot yield response to nitrogen rate. J. Production Agr. 10:336-339.

Sheppard, S.C. and T.E. Bates. 1986. Changes in nitrate concentration over winter in three southern Ontario soil profiles. Can. J. Soil Sci. 66:537-541.

Thorup-Kristensen, K. and R. van den Boogaard. 1999. Vertical and horizontal development of the root system of carrots following green manure. Plant Soil 212:145-153

Venter, F. 1979. Nitrate contents in carrots (Daucus carota L.) as influenced by fertilization. Acta Hort. 93:163-171.

Warncke, D.D. 1996. Soil and plant tissue testing for nitrogen management in carrots. Commun. Soil Sci. Plant Anal. 27:597-605.

Westerveld, S.M. 2002. Nitrogen management of cabbage, onions, and carrots as part of an integrated crop management program in Ontario. MSc Thesis, Univ. of Guelph, Guelph, Ont., Canada.

Westerveld, S.M. 2005. Nitrogen dynamics of the carrot crop and influences on yield and alternaria and cercospora leaf blights. PhD Diss., Univ. of Guelph, Guelph, Ont., Canada.

White, J.M. and J.O. Strandberg. 1978. Early root growth of carrots in organic soil. J. Amer. Soc. Hort. Sci. 103:344-347.

Wiebe, H.J. 1987. Effects of plant densities and nitrogen supply on yield harvest date and quality of carrots. Acta Hort. 198:191-198.

Zebarth, B.J., Y. Leclerc, G. Moreau, R. Gareau, and P.H. Milburn. 2003. Soil inorganic nitrogen content in commercial potato field in New Brunswick. Can. J. Soil Sci. 83:425-429. 